\title{
Consequences of Labour Migration from Tajikistan to Russia: About the Contemporary Socio-Economic State of Tajik Families
}

\author{
Sharif Y. Akramov \\ Furqat Sh. Akramov \\ Center for Social Demography and Economic Sociology, Institute of Socio-Political Research of RAS \\ Email: Sharif_akram@rambler.ru
}

\section{Doi:10.5901/mjss.2015.v6n3s4p231}

\section{Abstract}

The aim of the paper is to analyze the negative effects of labor migration from Tajikistan to Russia by the example of monitoring of socio-economic status of households in modern Tajikistan, which almost has lost its male population, who left for Russia to work. In this regard, the authors pose the following objectives: a) to identify the factors destructively affecting the condition of family relationships of migrant workers and divorce trends among labor migrants from Tajikistan to Russia; $b$ ) to produce a ranking of these factors; c) to characterize the modern households in Tajikistan. The study clearly states a trend for significant transformation of matrimonial attitude, family relations and sexual behavior in Tajikistan under the influence of intensive labor emigration. Multiple factors of this transformation can be selected. The study revealed several forms of transformation of family relationships, matrimonial attitudes and sexual behavior of migrant workers, which are reflected on families, with possibilities also to reflect on the demographic situation in Tajikistan in not-so-distant future.

Keywords: labour migration, demography, households, Tajikistan, Russia.

\section{Introduction}

A significant increase in labor migration from Tajikistan began in the mid-1990s., when the socio-economic situation in the country has deteriorated; it has forced many people to seek for work abroad. Although according to official contracts only 5-6 thousand man leaves from Tajikistan annually abroad (mostly in Russia and Kazakhstan), the actual size of labor migration (Bayzhigitov, 2014, Labor Migration (http://rus.kg/news/policy/8923-pyat-problem-kyrgyzsko-kazahskihotnosheniy.html)) is much more for much of the Tajik labor migrants gets a job on their own and does not get in the national statistics. The actual number of labor migrants from Tajikistan abroad is difficult to measure precisely. According to official Tajikistan statistics in mid-2000s there were 420 thousand people outside the country for temporary employment, including in Russia - more than 413 thousand, Kazakhstan - 4 thousand, in Kyrgyzstan, Belarus and Uzbekistan - 2 thousand, in Ukraine - about 1 thousand men. These data do not coincide with the results of research and data of foreign statistics. It is clear that in fact there are more Tajik migrant workers. The Research conducted at the beginning of the 2000s in Tajikistan by local experts showed that among labor migrants there were about 600 thousand citizens of Tajikistan, of which 85\% go to work precisely in Russia (Ryazantsev et al, 2014). According to the World Bank there were 791 thousand citizens of Tajikistan abroad in 2010, which was 11.2\% of the population (Migration and Remittances Fact book, 2011, p. 238). Tajik labor migrants work in almost all regions of Russia.

\section{Methodology}

The maximum number of migrants is concentrated in megalopolises (Moscow, Moscow region, St. Petersburg), as well as in border regions or closely located regions to Kazakhstan (Sverdlovsk, Novosibirsk, Tyumen, Samara, Chelyabinsk, Kemerovo Region, Krasnoyarsk Territory). The empirical base was compiled by surveys. According to a survey conducted among labor migrants from Tajikistan, the majority of migrants (69\%) worked in Russia for a verbal agreement. Only a quarter of migrant workers entered into a written contract to work. And only $23 \%$ of respondents had permission to work in Russia. Many people have great difficulties while traveling and working in Russia. In particular, about 53\% of the respondents answered that the most important challenges on the way to Russia was documents checking when crossing the border, about $44 \%$ of the respondents faced with exactions by customs officials, border guards and police. In Russia, many migrant workers from Tajikistan have poor working and living conditions. The study was conducted in two regions 
on the basis of two questionnaires, which were different, but and the same time similar in structure and scope of the phenomenon. The survey was conducted in Russian, Tajik and Uzbek languages.

The first questionnaire called "Tajik migrants, family and reproductive health" included 44 questions and focused on the citizens of Tajikistan (mostly men), who at the time of the survey were officially married or lived in cohabitation, in which the wife (husband) were in Tajikistan. Two hundred fourteen (214) respondents were interviewed in Moscow and the Moscow region. The sample was representative in terms of the three characteristics (sex, age, employment sectors in Russia) and was based on the data of the Federal Migration Service of Russia for socio-demographic composition and employment sectors of Tajik citizens who have received permission to work in Russia in 2011. To ensure the representativeness quota sample was used. The second questionnaire called "Tajik family and labor migration" included 50 questions and focused on Tajik citizens (mostly women) who at the time of the survey were permanently residing in Tajikistan, officially married or lived in a cohabiting with a spouse who recently (in over the last year preceding the survey) or at the time of the survey worked in Russia. On the basis of this questionnaire one hundred eighty six (186) respondents in various regions of Tajikistan were interviewed. A random sample was used, since accurate data on the socio-demographic structure of households in Tajikistan with migrant workers do not exist. The sample was random, reliability was provided by a selection of respondents in different types of settlements and the general geography of the survey. Processing of both surveys data were conducted in the SPSS software product. For a more detailed analysis the data on many issues in the two groups of respondents were compared; that allowed one to obtain more objective information about the impact of labor migration on family relations in Tajikistan on the basis of the views of two parties: the migrant workers in Russia and their spouses (husbands and wives) remaining in Tajikistan.

\section{Results}

Among Tajik labor migrants one can divide two groups. The first one - more numerous - are seasonal workers. Their flow is increased in the spring and summer, when they travel to Russia to work in agriculture and building. In the autumn they return home. According to rough estimates, in some regions of Russia the Tajiks account for about $75-80 \%$ of seasonal migrants. The second group of Tajik migrants - those who for a long time are located and are working in Russia, but have no legal status. Many of migrants work both legally and without official registration in the building, service sector, housing and communal services. Among labor migrants from Tajikistan men dominate.

Recently, however, the feminization of migration from Tajikistan takes place. Age composition depends on the sectors of employment. Among building workers there are more young people. In the building workers are working on the most difficult jobs that require endurance, physical strength and good health. Among agricultural workers and domestic workers there are more middle-aged people.

In ethnic structure the majority of labor migrants from Tajikistan are the Tajiks (300 Tajiks Await Deportation from Russia. In the: Arguments and Facts, 2011 http://www.aif.ru/society/news/99795). However, there are a considerable number of ethnic Uzbeks as well for the Republic of Tajikistan is home to more than 1 million Uzbeks.

Our research shows that about $40 \%$ of migrant workers live there where they work. Those are absolutely not adapted to life accommodations: attics, basements, buildings that are not completed or must be demolished, garbage shafts. According to a survey conducted among labor migrants from Tajikistan, the majority of migrants (69\%) worked in Russia for a verbal agreement. Only a quarter of migrant workers entered into a written agreement to work. And only 23\% of respondents had permission to work in Russia. Many of migrants have great difficulties while traveling and working in Russia. In particular, about 53\% of the respondents answered that the most important challenges on the way to Russia was documents checking when crossing the border, about $44 \%$ of the respondents faced with exactions by customs officials, border guards and police. In Russia many migrant workers from Tajikistan have poor working and living conditions. Typically, migrant workers come from Russia to Tajikistan, at best, 1 time per year. When it comes to seasonal employment, it is usually the winter time in Russia, when in such sectors as agriculture and building decline in activity is observed. Very rare migrant workers may visited by his wife. According to a survey only $10 \%$ of migrant workers were visited by their spouses during their work in Moscow, and by 22\% were rarely visited (Figure 1). 


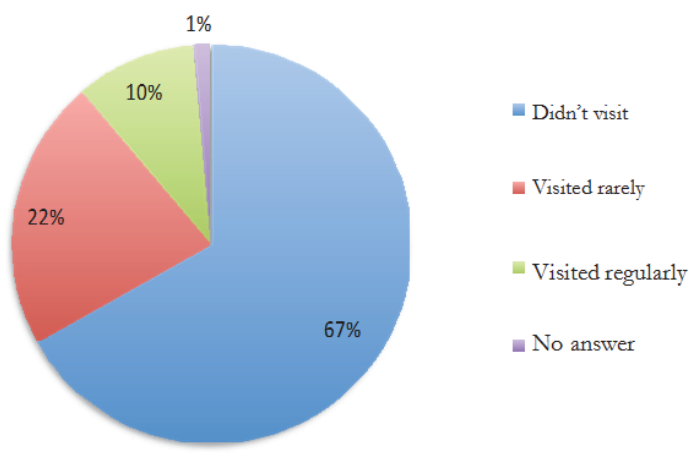

Figure 1. Distribution of answers of migrant workers to the question

"Did your spouse visit you during your work in Russia?" \% of respondents ( $N=214$ people in Russia)

Approximately half of Tajik migrant workers interrogated in Russia had sex with other partners, not their wives (husbands) (Figure 2). Moreover, 13\% of respondents had sexual contacts with other partners (except spouses) often! And only $52 \%$ of respondents did not have sex "on the side" while working in Russia. We believe that this represents a fundamental shift of sexual behavior of the Tajiks, at least of those who are involved in labor migration.

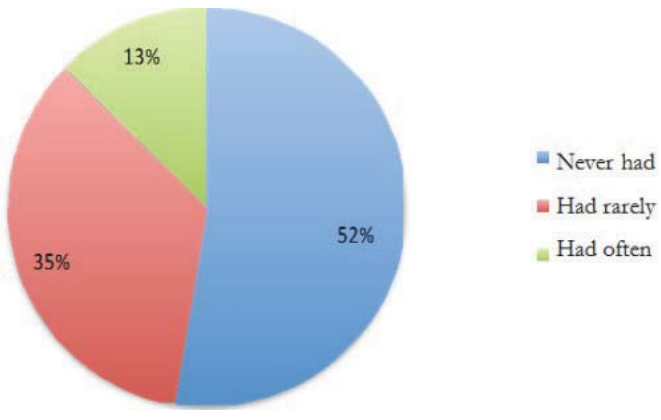

Figure 2. Distribution of answers of migrant workers to the question "Did you have sex during your stay in Russia with other partners (except your spouse)?", \% of respondents ( $N=214$ people in Russia)

The second way to meet the sexual needs of migrant workers is a "temporary wife", "guest marriage." This is a new phenomenon, which appeared as a result of the mass migration of the Tajiks to Russia. In the flow of migrant workers, as a rule, there are more young and middle-aged men. Many men usually rarely visit their family at home - in the best case every few months. Male migrant workers set up parallel family or cohabitation with Muscovite, or migrant women. In the migration environment "guest" marriage is become widespread. Often the old family gradually destroyed. "Guest" marriage in Tajikistan is a relatively new social and demographic phenomenon. It received a common spreading exactly among migrant workers. In modern scientific literature there is no single approach on the guest of marriage. "Guest marriage" most social scientists understand more as a forced condition of the person, rather than a free choice (E. Bosk, 2005, p. 12). According to another definition of "guest marriage" - this is a state where people support strong stable relationships (including sexual), a significant portion of their time together, and not much different from a married couple; except that they live at the same time apart and do not register their relationship officially. For example, many respondents before having "guest marriage" have lived in conventional (traditional) families. However, many researchers speaking of the "guest marriage", emphasize that official registration of spouses relations is also possible.

Despite the proliferation of "guest of marriage" among Tajik labor migrants, it has not yet become normal for the entire Tajik society. In Tajikistan, yet traditional attitudes to the need to create a family, strong family relationships and the presence of 3-5 children still preserved. However, the research found out a destructive impact of labor migration on family relationships in households whose representatives are involved in the movement. In particular, $12 \%$ of respondents in Tajikistan said that guess or assume that the spouse of their is unfaithful in Russia. Also, a fifth part of respondents are determined to break up in case of breach of faith (Figure 3). 


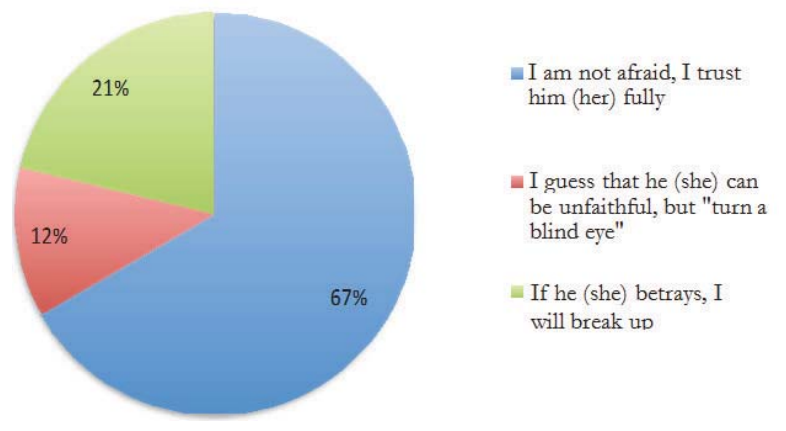

Figure 3. Distribution of the answers of wives (husbands) of migrant workers to the question "Are you afraid that the husband (wife) of yours betrays you in Russia?", \% of respondents ( $N=186$ people in Tajikistan)

The survey showed that in $60 \%$ of families in the long absence of one of the spouses misunderstanding and psychological problems in family relationships have arisen (Figure 4). In every sixth family new diseases arose that people associate with the absence of a spouse, or his trip abroad for temporary work, and in $9 \%$ of households earlier disease became more acute. In $13 \%$ of families conflicts and scandals because of the long absence of her husband became frequent. Approximately $3 \%$ of the respondents indicated other problems that have arisen in the family as a result of prolonged absence of a spouse due to labor migration in Russia.
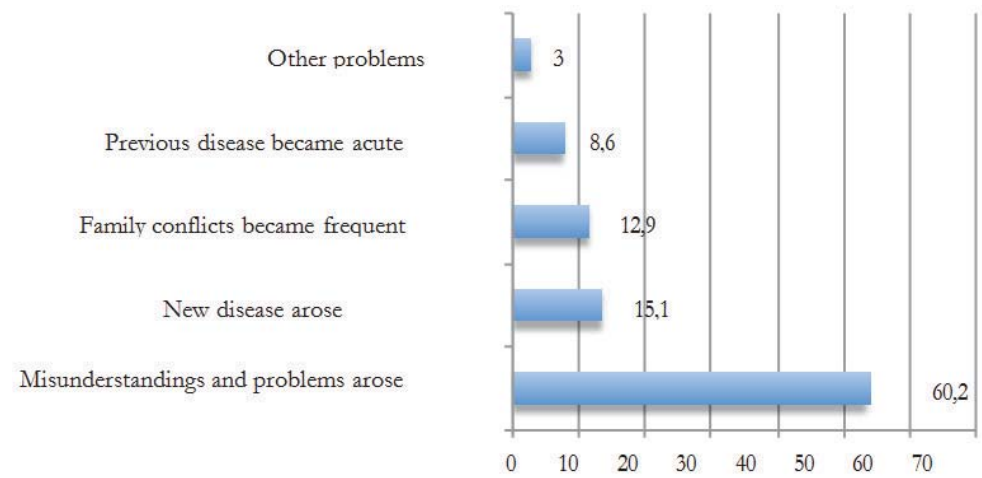

Figure 4. Distribution of the answers of wives (husbands) of migrant workers to the question "What are the problems in family relationships you have experienced because of a long absence of a spouse of yours?", \% of respondents (each respondent could give more than one answer) ( $\mathrm{N}=186$ people in Tajikistan)

In the course of sociological survey key problems with which one of the spouse remaining in Tajikistan is facing during the migration of another spouse were identified. Approximately half (45\%) of the respondents pointed out the lack of psychological contact, care and moral support from an absent spouse as the main factor (Figure 5). About $40 \%$ of partners in Tajikistan had experienced problems with the education of children and $32 \%$ - problems with housekeeping. Approximately $12 \%$ - lack of regular sexual relations with his (her) husband, who worked in Russia. Thus, one can say that the main factor of destructive relationships for Tajik families are moral and psychological circumstances that disrupt the traditional view of the role of spouses and families functioning. As for the prospects of family relations about $28 \%$ of respondents in Tajikistan believe that family breakup is impossible, but about the same (namely 26\%) of respondents believe that family breakup is possible (Figure 6). This is quite alarming and, more important, large-scale trend - one of four respondents worried that the family can fall apart. Fifth part of the partners in Tajikistan has not thought about it, and $23 \%$ believe that the strength of the relationship is affected not only by the distance or separation, but also by many other factors (relationships between spouses, parents experience, material wealth, and others). 


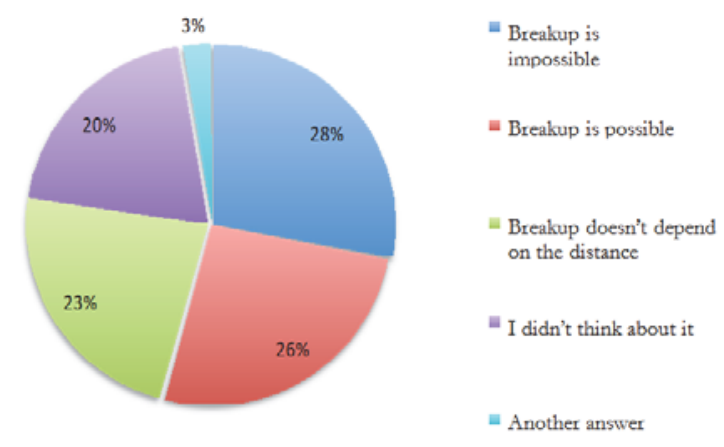

Figure 5. Distribution of answers of wives (husbands) of labor migrants on the question, "Are you afraid that the prolonged absence of a spouse can lead to your family breakup?", \% of respondents ( $\mathrm{N}=186$ people in Tajikistan)

To some extent the answers of the two groups of respondents to the question regarding the discussions of rupture of relations between spouses can be regarded as resulting indicator of divorce factors affection. The third part of labor migrants in Russia proves that sometimes such conversations arose in the family, as well as every fourth wife (husband) in Tajikistan confirm this. Often these problems occurred in 5\% of migrant workers surveyed in Russia and in $4 \%$ of their spouses in Tajikistan.

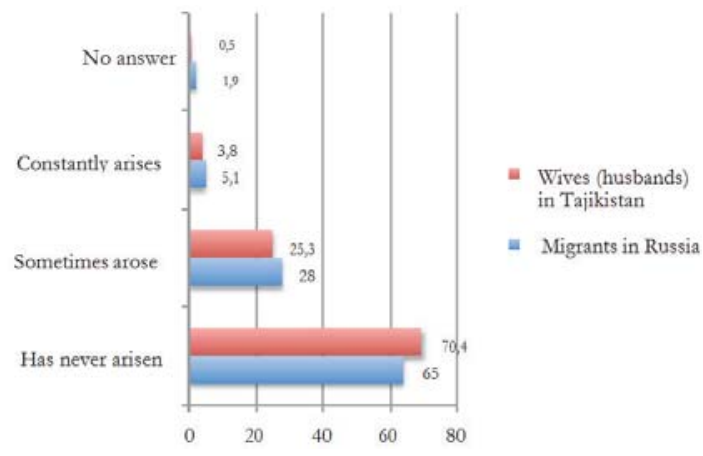

Figure 6. Distribution of answers of labour migrants and their wives (husbands) to the question "Have there been talk about divorce in your family recently? ", \% of respondents ( $N=214$ people in Russia and $\mathrm{N}=186$ people in Tajikistan)

Thus, labor migration significantly transform family relationships, matrimonial and sexual behavior of the population of Tajikistan involved in labor migration, which will have significant social and demographic consequences for the country in the short term.

\section{Discussion}

Studies show that 2.8-3.0 million undocumented migrant workers may be on the Russian labor market. And if one disseminate these figures on data of the structure of documented migration, in Russia there may be at least 1.5-2.0 million citizen of Central Asia that have not passed the registration procedures (migrants without residence registration and (or) work permit patent). In this case, remains the exploitation of migrant workers from Central Asia in the Russian Federation remains a serious humanitarian problem (Iontsev, Ivakhnyuk, 2012 \& Ryazantsev, 2006). In our opinion, the trend of the Tajik "guest marriage" based on Islamic culture, where, according to the Caranus, it is possible to enter into temporary relationships in the context of the so-called temporary marriage (i.e. orthi - marriage without obligations, muta (shige) - marriage for delight). This type of marriage may be concluded for a period of one hour to ninety-nine lunar years, but if spouses wish it may be renew in permanent marriage.

It should be noted that the Tajiks are Sunnis Muslims with Sufism clearly presented, also received widespread spreading among Muslims of Central Asia and Siberia (Foltz, 1996; Jonson, 2006; Karabulatova, Ermakova, Chiganova, 2014; Sayfulina at all., 2013 \& Karabulatova \& Sayfulina, 2015). In this connection, Tajiks polygamous family is a normal variant (Ryazantsev et al, 2014). In toto, trend in polygamous relationships attributes Tajik migrant workers to the risk group for the spread of many infectious diseases, including in reproductive and sexual sphere (Kil-Sang Y00, 2011; How to organize and protect migrant workers in agriculture and related industries, 2014 \& Olimova \& Bosk, 2003). Findings of 
the survey show that $9 \%$ of Tajik migrant workers in Russia suffered from venereal disease in the past three years, members of their families in Tajikistan, more than in $11 \%$ of cases. According to the survey of migrant workers in Russia $38 \%$ of them consulted a doctor on reproductive health issues in recent years. Appealability of their spouses in Tajikistan was lower and amounted to only 23\% (Ryazantsev et al, 2014). Hence, the problem itself Tajik labor migration is of polyaspect character.

\section{Concluding Remarks}

The study clearly states a trend for significant transformation of matrimonial attitude, family relations and sexual behavior in Tajikistan under the influence of intensive labor emigration. Multiple factors of this transformation can be selected. First, it is the scale of labor emigration. They are significant and affect almost every family in Tajikistan. Second, the socio-demographic composition of migrant workers, among those a large part is consisted of people of working and reproductive age. Most of them are young or middle-aged men. In the context of the traditional Tajik society marriages usually are entered to in very early age of 17-20 years. In a situation where the social basis of labor migration considerably expanded (youth is involved more often), many people postpone marriage and as a result increases the average age of marriage in Tajikistan and declination of birth rates in the country. Third, labor migration as a social phenomenon fundamentally changes the mentality of Tajiks involved in it, many of them after the experience of migration in Russia change their idea of family relationships and marriage. Many respondents adopt the Russian way of life, delay marriage and childbearing, easier refer to sexual partners change and divorce. Fourth, a separate long-term residence of the spouses, because of labor migration, often leads to the destruction of family relations, families breakup in Tajikistan. Fifth, labor migration gives the relative financial independence of a man who participates in it, which, together with other factors often alienates him from the traditional family models that exist in Tajikistan. The study revealed several forms of transformation of family relationships, matrimonial attitudes and sexual behavior of migrant workers, which are reflected on families, with possibilities also to reflect on the demographic situation in Tajikistan in not-so-distant future.

\section{References}

Akramov, F.S. (2006). Demographic Situation and Labor Migration from Tajikistan to Russia. Q.: The Practice of Foreign Labor Attracting and Using in Russia: Trends, mechanisms, technologies: Proceedings of the Theoretical-Practical Conference (the 16-17th of October, 2006). Ed. by prof. S.V. Ryazantsev, Moscow. pp. 5-8.

Bayzhigitov, N. (2014). Labor Migration (http://rus.kg/news/policy/8923-pyat-problem-kyrgyzsko-kazahskih-otnosheniy.html).

Jonson, L. (2006). Tajikistan in the New Central Asia, Published by I.B. Tauris. pp. 108.

Foltz, R. (1996). The Tajiks of Uzbekistan. Central Asian Survey, \#15(2), pp. 213-216.

Karabulatova, I.S., E.N. Ermakova \& G.A. Chiganova (2014). Astana in Kazakhstan and Astana in Siberia as a form of national islam of eurasia in the linguistic-cultural aspect. In the: Terra Sebus: Acta Musei Sabesiensis, Special Issue. pp. 15-30.

Karabulatova, I.S. \& Sayfulina F.S. (2015). Mytholinguistic Interpretation of Sacral Toponym Astana in Sociocultural Practice of the Siberian Tatars. In the: Asian Social Science. Vol 11, No.5. pp. 303-310.

Kil-Sang, Yoo (2011). Korea: Country Report, Migration and the Labour Market in Asia: Recent trends and policies, Tokyo, The Japan Institute of Labour. Migration and Remittances Fact book 2011, 2hd Edition, Washington DC, The World Bank.

Olimova, S. \& Bosk I. (2003). Labour Migration from Tajikistan. - Dushanbe: IOM.

Ryazantsev, S.V. (2010). Workers from Central Asia in the Housing and Communal Sector of Moscow (Working Paper). Working Paper, ILO Subregional Office for Eastern Europe and Central Asia. - M .: ILO.

Sayfulina, F.S., Karabulatova I.S., Yusupov F.Yus. \& Gumerov I.G. (2013). Contemporary issues of textual analysis of Turkic-Tatar literary monuments of Western Siberia/ In the: World Applied Sciences Journal Issue 27 (Education, law, economics, language and communication). pp. 492-496.

Iontsev, V.A. \& Ivakhnyuk I.V. (2012). Analytical Report on the Project: "The Role of International Labor Migration for the Economic Development of Russia", CARIM-East RR 2012/28, Robert Schuman Centre for Advanced Studies, San Domenico di Fiesole (FI): European University Institute.

Ryazantsev, S. (2010). Migrant workers from Central Asia in the housing and communal sector of Moscow, ILO.

300 Tajiks Await Deportation from Russia. In the: Arguments and Facts. - the 11vn of November, 2011 (http://www.aif.ru/society/ news/99795).

Ryazantsev, S.V. (2006). The Scale and Socio-economic Importance of Labor Migration for CIS Countries. In the: The Practice of Foreign Labor Attracting and Using in Russia: Trends, mechanisms, technologies. In .: Proceedings of the Conference (the 1617th of October, 2006). - M. pp. 85.

Ryazantsev, S.V., Pismennaya E.E., Karabulatova I.S. \& Charif Y. Akramov (2014). Transformation of sexual and matrimonial behavior of Tajik labor migrants in Russia. In the: Asian Social Science. Vol 10, No.20. pp. 174-183.

CIS Statistics: Statistical Bulletin (2005). № 15 (366), August, 2005. pp. 55. 